This item was submitted to Loughborough's Research Repository by the author.

Items in Figshare are protected by copyright, with all rights reserved, unless otherwise indicated.

\title{
The criminal histories of drug-drive offenders
}

\section{PLEASE CITE THE PUBLISHED VERSION}

https://doi.org/10.1093/police/pay026

\section{PUBLISHER}

Oxford University Press (@ The Author)

\section{VERSION}

AM (Accepted Manuscript)

\section{PUBLISHER STATEMENT}

This is a pre-copyedited, author-produced version of an article accepted for publication in Policing following peer review. The version of record NUNN, J., 2018. The criminal histories of drug-drive offenders. Policing: A Journal of Policy and Practice, 14 (2), pp.456-468 is available online at:

https://academic.oup.com/policing/article/14/2/456/4967630 and https://doi.org/10.1093/police/pay026.

\section{LICENCE}

CC BY-NC-ND 4.0

\section{REPOSITORY RECORD}

Nunn, James. 2018. "The Criminal Histories of Drug-drive Offenders". Loughborough University. https://hdl.handle.net/2134/35206. 


\begin{abstract}
This study examined the previous criminal behaviour of individuals who were arrested for violating the drug driving over the prescribed limit offence, introduced into the United Kingdom (UK) in March 2015. The sample consists of individuals arrested during the first year of enforcement of this offence from March 2015 to March 2016 within the jurisdictional boundaries of the Metropolitan Police Service in London. The previous criminal behaviour of the research subjects was framed within a number of criminological theories and there is examination of any correlation between their criminal history and the drug driving offence they had been arrested for. The criminal activity was obtained from each individual's criminal record held on the police national computer and coded with regards to offence groups. As well as criminal sanctions there was also an examination of drug related arrest histories. The results indicate a high level of previous criminal activity with drugs and driving matters dominating that activity. This supports the construct that, in this context drug driving fits within their patterns of offending.
\end{abstract}




\section{The Criminal Histories of Drug Drive Offenders.}

\section{Introduction}

Road and traffic policing are focussed on safety related matters and efforts to reduce the impact on society created by collisions (Groeger, 2011; Bates, Soole and Watson, 2012; College of Policing, 2013) as well as tackling road related criminal activity and terrorism (College of Policing, 2013). The taking of intoxicating substances has an impact on both cognitive function and psychomotor skills which can have an impact on the ability to drive motor vehicles safely (Moskowitz, 1976; Berghaus, Scheer and Schmidt, 1995; Bernhoft, 2011; Department for Transport, 2013). There is a correlation between having drugs in the blood stream and being involved in collisions which cause injury (Clarke et al., 2010; Bernhoft, 2011; Department for Transport, 2013). In order to reduce such collisions, it is essential to have understanding of the nature of the individuals concerned and to be able to put their offending in context and enhance the effectiveness of intelligence-led targeted enforcement as part of an overall enforcement strategy (Bates, Soole and Watson, 2012).

Most of police traffic enforcement is based on a grounding of deterrence theory (Stafford and Warr, 1993; Tay, 2005; Bates, Soole and Watson, 2012; Allen, Murphy and Bates, 2015; Watson et al., 2015a). However, for some offenders the deterrent effect may not be sufficient if the offending fits within their usual pattern of routine recidivist behaviour (Stafford and Warr, 1993; Farrington et al, 2006; Bates, Soole and Watson, 2012; Macleod, Grove and Farrington, 2012). This article aims to add further richness to the knowledge relating to motoring offenders and previous criminal history by examining the paradigm of road traffic offending by focussing on drug driving and places it primarily in the theoretical context of behavioural theories. If the offending is part of individual's pattern of behaviour then this has implications for the interventions designed to reduce the offending. The criminal history data also adds further evidence to support the theory of Self-Selection Policing, although how recent the criminal convictions were to this current offending was not part of the original data gathered in the study (Roach and Pease, 2016; Roach, 2017).

\section{Behavioural Theories}

There are a number of inter-related behavioural theories which can frame offending such as Routine Activity and Rational Choice (Clarke and Felson (1993). Routine Activity Theory, for example, positions crime commission as intimately entwined with social life 
and its varied interactions (Felson, 1986; Brantingham and Brantingham, 1993), intimating that offenders are little different from the rest of the general population (Rock, 2012). Everyday life creates a web of interactions encompassing many routine activities that may result in criminal opportunity and encounters with those entrusted to prevent it (Felson, 1986), suggesting that the relationship between conventional and illegal activities is symbiotic in nature.

Once the criminal opportunities arise, the offender then needs to make the rational choice regarding whether or not to take that opportunity with Newburn (2009) observing that '...human beings are rational actors and that rational calculation plays an important part in decision-making, including decision-making about offending...' (p.302). The commission of the offence can be seen as a culmination or 'end point' of any decision-making process or decision script (Brantingham and Brantingham, 1993, p. 261). Any rational choice made by individuals is subjective, context driven, linked to their routine activities and subject to any impaired, possibly through drug taking, thought process (Felson, 1986; O'Grady, Asbridge and Abernathy, 2000; Miller, 2013)

Involvement in drug dealing or the drugs trade may well be completely rational for some individuals (Jacobs, 1999) and the choice to consume cannabis can be the balance of pleasure and the risk of sanction (Paternoster, 1989; O'Malley and Valverde, 2004).

Individual's subjective choices regarding the situations and opportunities they find themselves in are influenced by a combination of social interaction and socialisation, these can be intertwined with habitual behaviour and any subcultural context they choose to embrace (Cohen, 2005).

Routine activity theory is generally contextualised around the interaction of suspects, victims and the circumstance within an exploitative crime paradigm (Felson, 1986). However, it can also be considered in relation to crime that has been deemed 'deviance' by wider society and is contrary to what is deemed to be conventional normative standards (Osgood et al., 1996). In the case of drug driving there is clear evidence of increased risk to other societal members as well as the perpetrators, and the use of routine activity theory has been considered appropriate when focusing on the related matters of drug use and general driving matters, although not specifically drug drive (Osgood et al., 1996). 
Any activity is generally framed in the context of being beneficial to the individual concerned, with the choice to take advantage of that benefit. As 45.5 million individuals hold driving licences in the UK (Driver and Vehicle Licencing Authority, 2015), this suggests that the driving of motor vehicles is a routine beneficial activity for independent travel. Equally it may be true to say that for certain segments of society drug taking is fixed as part of their social interaction and can be considered a routine activity (Osgood et al., 1996; Deehan and Saville, 2003). The intoxication produced in the taking of drugs produces a beneficial psychological impact in altering the way the subject feels (Rado, 1957: Conner, Sherlock and Orbell, 1998; Orbell et al., 2001; Bancroft, 2009).

Therefore, if an individual as part of their routine activities chooses to both drive and takes drugs, they may also routinely choose to drive with drugs in their systems. In the past this may also have been the case for drinking and driving; however, there has been a shift in societal attitude towards this behaviour making it less socially acceptable (Grasmick, Bursik and Arneklev, 1993; Freeman et al., 2006; Reed et al., 2010).

Offender's criminal histories give insight into the breadth of their offending and can result in them self-selecting themselves for police attention. Offenders commit offences across many offence types and the examination of a propensity for certain offences may be an indicator of likely involvement in other and/ or more serious offending (Roach and Pease, 2016; Roach, 2017).

This study will examine if there is a relationship between drug driving involvement and other drug and serious driving offences within a wider criminal history. Criminal convictions and sanctions are also an indication of criminal activity, although they do certainly not reflect the full involvement of individuals (Blumstein and Cohen, 1979; Farrington et al., 2006; MacLeod, Grove and Farrington, 2012). The nature of offences recorded may reflect the crime dominant in an individual's behaviour patterns at any particular time with drugs offences appearing to be something of a specialism and more likely to be repeated than other crime types (MacLeod, Grove and Farrington, 2012).

The UK Ministry of Justice publishes annual statistics relating to the criminal justice system. In these statistics there is reference to a category of individuals defined as 'Persistent Offenders', this is not defined in statue but is a construct related to offending which allows the criminal justice system to view individuals differently. These individuals are defined as those with eight or more previous criminal sanctions and in the reported 
figures for 2015 these individuals actually had an average of 22 previous criminal sanctions. Of the 1.7 million individuals interacting with the criminal justice system in 2015, 236,000 were designated as persistent offenders which equates to $14 \%$ of the total (Ministry of Justice, 2016). Certainly, being a persistent offender can have an impact on how individuals are viewed and dealt with by the criminal justice system and being a persistent offender opens different sentencing options (Crown Prosecution Service, 2014; 2016b).

\section{Drug Driving offences in the UK}

Driving under the influence of drugs to the point where ability was impaired to the level of unfitness has been an offence under section 4 Road Traffic Act 1988 since its inception. However, there had not been an offence of driving with drugs to a prescribed limit, that is, with a concentration in blood beyond a predetermined level, as there had been for alcohol. In 2015, after considerable consultation, a new offence of driving with certain specified drugs in your blood to prescribed limits was introduced and incorporated into the Road Traffic Act 1988 as section 5A. This section specified 17 controlled drugs including both illicit drugs of abuse, and prescription medication which had a tendency to be abused. Each drug has its own specific blood concentration limit. The offence is split into 3 options depending on the actions of the subject, these are straightforward driving, being 'in charge' of the vehicle concerned, or attempting to drive.

The powers to take samples already contained in the act were extended to cover the new offences. Devices for the screening of oral fluid for drug content at the roadside were approved; however, of the 17 specified controlled drugs where prescribed limits were set, devices were only approved initially for two drugs: Cannabis and Cocaine.

\section{Previous Studies}

An examination of the literature has found no published research examining the link between drug driving and prior criminal offending. Rose (2000) examined the previous offending of drink drivers and disqualified drivers. The research was a UK Home Office study which examined any relationships between serious traffic offenders and their criminal history. This showed that disqualified drivers, that is, those individuals disqualified from driving by a court, had very similar offending profiles to other mainstream offenders, some $72 \%$ had a criminal record. However, for drink drive offenders only $40 \%$ had a 
criminal record. Even this level was thought to be around twice that of the general population. This study concludes that serious traffic offenders are criminals and not representative of the general population.

Broughton (2007) examined motoring offenders in general to ascertain any correlation to other offending. In examining data over a four-year period with between $75 \%$ and $87 \%$ of the motoring offenders also having another non-motoring conviction,

Watson et al. (2015b) examined the criminal histories of high risk speeding offenders and found a correlation with both having a criminal record and being involved in drugs offences.

Roach (2017) also examined the offending of disqualified driving from the perspective of this offending being suitable as a trigger offence within self-selection policing (Roach and Pease, 2016). In this research $86 \%$ were found to have previous criminal convictions with an average of 14 offences. In this context disqualified driving was found to be suitable.

\section{Method}

The data used in this research relates to the geographical policing area covered by the Metropolitan Police in London. The data spans the first year of enforcement in the city covering from $2^{\text {nd }}$ March 2015 to $2^{\text {nd }}$ March 2016.

The results presented were sourced from the police computer system which records arrests and will include both demographic and criminal history data. When a subject is arrested for a drug drive offence they are removed to a custody suite where their personal and other details are recorded. The subjects are also finger printed which allows their identity to be confirmed and cross referenced with any criminal record. This data was obtained by an internal search of the custody computer system.

The initial dataset was received as an Excel spreadsheet and contained all the arrest data for offences under sections's 4, 5 and 5A Road Traffic Act 1988, these being all the drink and drug driving offences. This data was sanitised to produce a sample which only contained matters under section $5 A$. This sample of individual arrests was examined to determine if any individuals featured twice or more. So that any individual criminal record would not be double counted the number of individual offenders involved was determined and collated to produce the study sample for further analysis. Due to the straightforward 
analysis undertaken in this paper the data was left in Excel. The criminal record system holds details of both arrests and convictions and is linked to a particular set of fingerprints.

The data from the custody system was then extended with details of the criminal records held on the individuals. A criminal record is generated in the UK when an individual is dealt with by the criminal justice system. The criminal career information is stored on the Police National Computer and individuals are allocated a criminal record number. These are usually referred to as a CRO number which refers to the Criminal Record Office which was the original depository of the information (MacLeod, Grove and Farrington, 2012; Home Office, 2014b).

The criminal record holds information on convictions or other criminal justice sanctions, such as, cautions, reprimands, warnings and penalty notices for criminal offences which are designated as recordable, as well as an arrest summary (Home Office, 2014b).

Convictions are recorded against a subject when they attend a criminal court to answer a criminal matter and are either found guilty, following a trial, or they plead guilty during the procedure, resulting in a recorded criminal sanction. Cautions, reprimands, warnings and penalty notices are alternative methods of dealing with criminal matters. They are described as 'out of court' disposals, as they avoid the involvement of the criminal court system. 'Out of court' disposals have strict criteria and there must have been an admission of guilt and sufficient evidence for a successful prosecution (Crown Prosecution Service, 2016a).

For each individual with a criminal record a number of details were obtained, such as the numbers of arrests and convictions. Also, the specifics of drugs related arrests and all the other offences resulting in a criminal case disposal were recorded. To assist with continuity this data was also handled in Excel. The data for convictions and arrests was coded by the author.

There are a considerable number of circumstances which may result in offending behaviour not resulting in a criminal conviction. Many of these factors involve the processes of the criminal justice system and the number of steps in the system at which decisions are made regarding continuance; there will also be decisions regarding the seriousness of the offence that proceeds. A measure that may be better as a reflection of 
criminal activity is the number of times a subject is arrested for a particular offence. A subject's criminal record also holds information regarding their arrest history.

Each arrest will result in an entry, details of the offence(s) and other material relating to the process. This data is kept separately from the sanctions within the system. For the purposes of this research and to allow comparison with conviction data the arrest history was examined for arrests relating to drugs offences under the Misuse of Drugs Act 1971 and the nature of the offences concerned, the initial coding.

The second coding regarding drug arrests related to the seriousness of the drug offence involved. The coding took account of the nature of the drug offence, identifying offences which could be considered more serious than merely possession of a substance. The nature of these more serious offences encompassed constructs such as possession with intent to supply (PWITS); supply or supplying; producing or production and conspiracy offences related to supply and production.

Once the data had been obtained the information was coded to show involvement, or not, in the particular category under investigation. This coding allowed the calculation of proportion for each of the categories concerned and these have been expressed as both a numeric count and a percentage proportion. The offences were grouped according to their statute or similarity.

\section{Results}

During the period $2^{\text {nd }}$ March 2015 to $2^{\text {nd }}$ March 2016 there were 842 arrests $(n=812$ individuals). The offence has three options (as mentioned earlier) for the driver's activity in relation to the vehicle concerned. The arrests were distributed between driving $(n=797$, $94.7 \%)$, being in charge $(n=38,4.5 \%)$ and attempting to drive $(n=7,0.8 \%)$. Of those arrested 14 were arrested for two offences on a single occasion and 16 multiple times.

\section{Demographic Data}

On arrest the gender of the detainee is recorded. The distribution was male $n=780(96 \%)$ and female $n=32(4 \%)$.

Ages ranged from 15 to 77 (Mean $=28.6$, median $=26$ and $\sigma=8.6$ ). Figure 1 demonstrates that while most individuals arrested were under the age of 40 . 


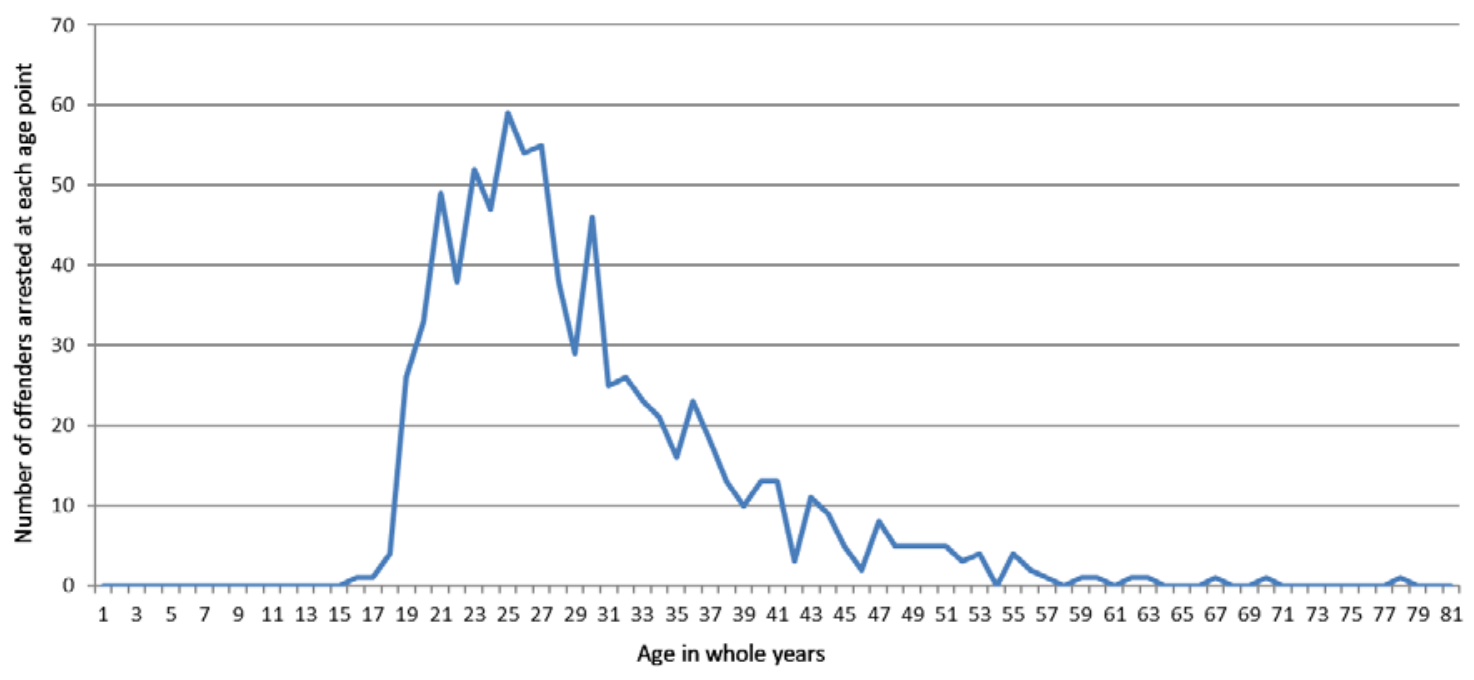

Figure 1. Age distribution of drug drive offenders.

\section{Criminal Record}

Within the sample, $82 \%$ had a prior criminal record $(n=663)$. These 663 individuals had been previously arrested for 9410 offences at an average of $14(\sigma=13)$ each.

\section{Previous Arrests for Drug Offences}

Of the total sample with a criminal record, 592 (89\%) of the individuals had been arrested for a drugs offence, with 318 (54\%) having been arrested for one or more of the more serious drugs offences. Only 16 of this latter group did not have a corresponding or other arrest for possession offences.

\section{Previous Convictions and other Sanctions}

Within the population included in this analysis 389 of the 663 individuals (57\%) with a criminal record met the definition of a persistent offender. These offenders can be reasonably considered what MacLeod, Grove and Farrington, (2012) would term high-risk/ high-rate offenders.

All the offences that the subjects had received a criminal sanction in relation to were recorded in the analysis. Due to the complexity and diversity of statute the offences were grouped together into crime type categories. The number of subjects with sanctions within each category was then calculated and the results are shown in table 1 below starting with those that had the highest incidence. It is worth noting that many motoring convictions do 
not appear within an individual's criminal record but are recorded on their driver record.

Driver record data is beyond the scope of this paper.

\begin{tabular}{|c|c|c|c|c|}
\hline Offence Category & $\begin{array}{l}\text { Statute included, offences } \\
\text { contrary to - }\end{array}$ & $\begin{array}{l}\text { Number of } \\
\text { subjects with } \\
\text { this offence type } \\
n=\end{array}$ & $\begin{array}{l}\text { Proportion of } \\
\text { those with } \\
\text { criminal record }\end{array}$ & $\begin{array}{l}\text { Proportion of } \\
\text { the total } \\
\text { population }\end{array}$ \\
\hline Drugs offences & Misuse of Drugs Act 1971 & 545 & $82 \%$ & $67 \%$ \\
\hline $\begin{array}{l}\text { Recordable } \\
\text { Motoring Offences }\end{array}$ & $\begin{array}{l}\text { sections's 1-7 Road Traffic Act } \\
1988 \text { (Standard of driving } \\
\text { offences and drink and drug } \\
\text { driving, note offences under } \\
\text { section } 5 \text { A which resulted from } \\
\text { arrests during the designated } \\
\text { timeframe were disregarded) } \\
\text { section } 87 \text { Road Traffic Act } \\
1988 \text { (Driving not in } \\
\text { accordance with a licence) } \\
\text { section } 103 \text { Road Traffic Act } \\
1988 \text { (Driving whilst } \\
\text { disqualified) } \\
\text { section } 143 \text { Road Traffic Act } \\
1988 \text { (No insurance) } \\
\text { section } 163 \text { Road Traffic Act } \\
1988 \text { (Failing to stop for police) } \\
\text { section } 173 \text { Road Traffic Act } \\
1988 \text { (Forged document } \\
\text { offences) }\end{array}$ & 353 & $53 \%$ & $43 \%$ \\
\hline $\begin{array}{l}\text { Dishonesty } \\
\text { Offences }\end{array}$ & $\begin{array}{l}\text { Theft Act } 1968 \\
\text { Fraud Act } 2006 \text { (Including } \\
\text { repealed versions previous } \\
\text { within Theft Act 1968) }\end{array}$ & 353 & $53 \%$ & $43 \%$ \\
\hline Assaults & $\begin{array}{l}\text { section's 18, 20, } 38 \text { and } 47 \\
\text { Offences Against the Persons } \\
\text { Act } 1861 \text { (Grievous bodily harm }\end{array}$ & 227 & $34 \%$ & $28 \%$ \\
\hline
\end{tabular}




\begin{tabular}{|c|c|c|c|c|}
\hline & $\begin{array}{l}\text { with intent, grievous bodily } \\
\text { harm, assault with intent to } \\
\text { resist arrest, and actual bodily } \\
\text { harm) } \\
\text { section } 39 \text { Criminal Justice Act } \\
1988 \text { (Common assault and } \\
\text { battery) } \\
\text { section } 46 \text { Police Reform Act } \\
2002 \text { (Assault on a designated } \\
\text { and accredited person) } \\
\text { section } 89 \text { Police Act 1996 } \\
\text { (Assault on a constable (and } \\
\text { prison officers by virtue of } \\
\text { section } 8 \text { Prisons Act 1952)) }\end{array}$ & & & \\
\hline Public Order & $\begin{array}{l}\text { section's 1-5 Public Order Act } \\
1986 \\
\text { Protection from Harassment } \\
\text { Act } 1997 \\
\text { section } 91 \text { Criminal Justice Act } \\
1967 \text { (Drunk and disorderly) } \\
\text { section } 1 \text { Public Meeting Act } \\
1908 \text { (Disorderly behaviour at a } \\
\text { public meeting) } \\
\text { Outraging Public Decency } \\
\text { under Common Law }\end{array}$ & 212 & $32 \%$ & $26 \%$ \\
\hline Weapons offences & $\begin{array}{l}\text { section } 1 \text { Prevention of Crime } \\
\text { Act } 1953 \text { (Possession of an } \\
\text { offensive weapon) } \\
\text { section } 139 \text { Criminal Justice } \\
\text { Act } 1988 \text { (Possession of an } \\
\text { article with a point or blade) } \\
\text { Firearms Act } 1968\end{array}$ & 156 & $24 \%$ & $19 \%$ \\
\hline
\end{tabular}

Table 1: Criminal sanction incidence.

\section{Limitations}


There are a number of limitations to this research which may make the results unsuitable for generalisation. This analysis looked at a specific timeframe and gathered data from the first year of enforcement. Although there had been publicity regarding the introduction, it is likely that a lack of awareness may be reflected in the population. This research has not examined that aspect.

The research was based on data from the Metropolitan Police Service in London. London has a unique sociodemographic makeup and night-time economy that is arguably unlikely to be reproduced elsewhere.

The officers enforcing the new legislation were specially trained prior to the introduction of the offence and were specialist roads policing officers. They also had limited capacity to enforce. Therefore, the enforcement may have been subject to both conscious and unconscious bias which may not be present if the enforcement was undertaken by alternate officer groups in alternative paradigms. Due to the restriction on the level of enforcement this research is unlikely to reflect the true level of offending, will only account for a proportion of the subjects driving under the influence of drugs in the driving population and this cohort may not be representative. These limitations may restrict how these findings may be generalised.

\section{Discussion}

This article set out to determine if there was any significant correlation between being arrested for drug driving and a subject's previous offending history. The proposal was that drug driving as a distinct behaviour, is part of the routine chosen behaviour of the individuals concerned. The research examined the arrest and conviction histories of the subjects to identify indications that they are involved in the elements of the offence namely drug taking and driving in contravention of the law.

\section{Key Findings}

Examination of the demographic data analysed allows an assessment of the population in the wider context and a judgement regarding the validity of the overall finding. Two variables were examined relating to the demographics of the subjects. Demographics can have an impact on offending in general.

\section{Gender}


There was a very clear gender bias in the population. This is consistent with research that shows a relatively low proportion of offending is undertaken by women due to many factors (Hagan, Simpson and Gillis, 1979; Grasmick and Bursik, 1990; Steffensmeier and Allan, 1996; Silvestri and Crowther-Dowey, 2016), with Heidensohn $(1968 ; 2010)$ observing that this position has been stable over time. Statistics from the Ministry of Justice (2014) reinforce this, showing women only accounted for $15 \%$ of the total arrests in 2013 , raising slightly to $20 \%$ when summary only motoring offences are removed from the calculation.

There is clear evidence of lower female offending in relation to drugs (Silvestri and Crowther-Dowey, 2016), reinforced by Ministry of Justice (2014) statistics showing drugs offences accounted for only $8 \%$ of all female arrests. The Crime Survey for England and Wales 2013-2014 in response to the question regarding drug use in the previous year showed a clear male dominance (11.8\% of men, $5.8 \%$ for women) (Home Office, 2014a).

\section{Age}

The age distribution of the subjects gave a range from 15 years to 77 years with a significant peak from 18 years to 35 years with the distribution skewed to the right. Mean age was 28.6 years, median 26 years and $\sigma=8.6$ years.

This distribution appears to be consistent with and reflects research regarding offending and age (Sampson and Laub, 1990; Warr, 1998; MacLeod, Grove and Farrington, 2012; Home Office, 2014a).

\section{Arrests and Convictions}

It is clear from the analysis of arrests and convictions that the population contained a significant number of offenders and was not a reflection of the general population, driving population or criminal population. The sample from the population who had been involved with the criminal justice system prior to their arrest for drug driving included a significant proportion who had been involved in drugs offences and serious motoring offences amongst a very varied offending history. It also contained a significant number of persistent offenders ( $n=392$ or $59 \%$ ) with an average number of criminal sanctions of 23 compared to the population containing all persons arrested for any offence, which for 2015 stood at $14 \%$ of the 1.7 million individuals, with an average number of criminal sanctions of 22, dealt with by the criminal justice system (Ministry of Justice, 2016). 


\section{Drugs Arrests}

The subjects with a criminal record had been arrested on average 14 times prior to being arrested for drug driving and significantly $89 \%$ had arrest records for drugs offences of which 54\% had been arrested for serious drugs offences over and above mere possession. This is despite research which suggests the use of illicit drugs within the general population is relatively low at around 3\% (Home Office, 2014a).

\section{Recordable Motoring Offences}

The proportion of these subjects with a conviction for a serious motoring offence, $53 \%$, is significant as many of the recorded offences are not ones where the subjects are arrested directly but are often as a by-product of other offending. Equally the level of offending recorded in the subject's criminal record is unlikely to be a true or complete record of their motoring offending as many road traffic matters are dealt with in such a way as they are only reflected in the subject's driver record and not their criminal record.

\section{Theoretical context}

This study tested whether the examination of previous offending histories could be framed within routine activity theory, rational choice theory and self-selection policing theory within the context of a drug driving population. The results indicate that there was a high level of recidivism within the population with $82 \%$ of those caught drug driving having a criminal record. Of those with a criminal record $59 \%$ were persistent offenders. This finding is consistent with Rose (2000), Broughton (2007), Watson et al. (2015b) and Roach (2017) in relation to other motoring offending. Rose (2000) in researching disqualified drivers, found that $72 \%$ had a criminal record. The same analysis also showed that $40 \%$ of drink drivers had a criminal record, still some twice the general population. This latter comparison may be related to the consumption of alcohol being legal. Broughton (2007) looking at general motoring offenders found between 75 and $87 \%$ had previous convictions. Watson et al. (2015) found that $55.2 \%$ of high range speeding offenders had previous criminal histories with drugs offences the second most prevalent. Roach (2017) in the most recent study found remarkably similar levels of previous offending and volume of offending to this study within disqualified drivers.

The study population not only had a high level of previous offending but that offending was dominated by the two constituent parts of the offence of drug driving, that being the taking 
of illicit drugs, and driving in such a manner as to disregard road traffic law. The drugs related offending also goes beyond possession to more serious drug offences; this suggests that the subjects may have a far higher involvement in drugs subculture than either the general population or even the general offending population. This level of involvement would suggest that both these factors could be considered part of the subject's routine societal interaction and the results would tend to support the proposal that this offending is part of their routine chosen behaviour.

Until the introduction of the new offence, by the UK government, gave the police the power to deal with this routine behaviour offenders had been able to drive under the influence of drugs with impunity as long as they were not so intoxicated as to be unfit. The new offence disrupts that behaviour and this research gives insight into the initial impact of the enforcement.

What has become clear is that the population examined in this study is not a reflection of either the general population or even the general driving population. This may mean that any activity, framed in the context of the three E's that is, Education, Engineering and Enforcement, towards reducing this offending may need to be targeted at specific groups (Zaal, 1994; OECD, 1997; Groeger, 2011).

\section{Consideration for Future Research}

One of the major considerations in introducing the new offence was on the grounds of road safety, as the consumption of drugs may be a factor in the level of serious collisions. Further research could be carried out to ascertain if this situation has persisted or changed following the introduction of the offence.

The responsibility for introducing enforcement was delegated to the 43 individual police services in England and Wales. Each introduced the enforcement to their own design as each had different criteria and capacity. Research could establish if these variations had any impact on either the scope of enforcement, effectiveness or the impact on other factors such as collisions or casualties.

That such a proportion of the subjects are involved in the drugs subculture would open the possible hypothesis that the introduction of this legislation may have a wider impact. Research could examine some of these aspects including, for example, changes in drug 
consumption habits among users subject to this enforcement. This could be linked to wider research into societal attitudes toward drug use and this specific offending.

\section{Conclusion}

The demographic analysis is consistent with the results that would be expected from an offending population. This suggests that this sample of drug drivers may be a fair representation of the whole population. The results of this study show a high proportion of drug drive offenders had extensive and varied criminal histories and is similar to the findings of Rose (2000) and Roach (2017) in relation to disqualified drivers. The conclusion is that serious traffic offenders are criminals with more similarities to mainstream offenders than the general public is equally applicable to the findings of this study. There is clear correlation between drug offending, serious traffic offending and drug drive offending and each may prove suitable as a trigger offence for the other within a selfselection policing nexus.

Previous studies have shown that the proportion of drink drivers with previous criminal histories Rose (2000) is significantly lower than the proportion of drug drivers with previous criminal histories found in this study. This will have an impact on the intervention method required to reduce this type of offending. General education and societal influence that have worked over the long term with drink drive offending may not be as effective with the recidivist criminals within this population. The balance of education and enforcement may need to be different. Altering the quality of decision making, which dictates the choices that individuals make, can be difficult. Garland (2009) frames the difficulty as being caused by individuals 'whose attitudes cannot be changed...' (p. 305). Any activity focussed on reducing this type of offending will need to use methods that are effective against recidivist criminality.

This study indicates that the examination of previous offending is supportive of the constructs of Routine Activity Theory and Rational Choice Theory. It is also appropriate to fit within Self Selection Policing theory in this specific paradigm.

\section{References}

Allen, S., Murphy, K. and Bates, L. (2015) 'What drives compliance? The effect of deterrence and shame emotions on young drivers' compliance with road laws', Policing and Society, published online. Available at: 
http://www.tandfonline.com/doi/full/10.1080/10439463.2015.1115502?scroll=top\&needAcc ess=true (Accessed: 27 June 2017).

Bancroft, A. (2009) Drugs, Intoxication and Society. Cambridge: Polity Press.

Bates, L., Soole, D. and Watson, B. (2012) 'The effectiveness of traffic policing in reducing traffic crashes', in Prenzler, T. (ed.) Policing and Security in Practice: Challenges and Achievements. Basingstoke: Palgrave Macmillan. pp. 90-109.

Berghaus, G., Scheer, N. and Schmidt, P. (1995) 'Effects of Cannabis on Psychomotor Skills and Driving Performance - A Metaanalysis of Experimental Studies', 13th International Conference on Alcohol, Drugs and Traffic Safety. Adelaide, Australia, 13-18 August. Available at: http://www.icadtsinternational.com/files/documents/1995 060.pdf (Accessed 29 June 2017).

Bernhoft, I.M. (2011) Results from epidemiological research - prevalence, risk and characteristics of impaired drivers, Druid project report. Available at:http://www.druidproject.eu/Druid/EN/deliveraleslist/downloads/Deliverable 24 1.pdf? blob=publicationFile\&v=1 (Accessed: 29 June 2017).

Blumstein, A. and Cohen, J. (1979) 'Estimation of individual crime rates from arrest records', Journal of Criminal Law and Criminology, 70(4), pp. 561-585.

Brantingham, P.L. and Brantingham, P.J. (1993) 'Environment, Routine, and Situation: Towards a Pattern Theory of Crime', in Clarke, R.V. and Felson, M (eds.) Routine Activity and Rational Choice: Advances in Criminological Theory, Volume 5. New Brunswick: Transaction Publishers.

Broughton, J. (2007) 'The correlation between motoring and other types of offence'. Accident Analysis and Prevention, 39, pp. 274-283.

Clarke D.D., Ward, P., Bartle, C. and Truman, W. (2010) 'Killer crashes: Fatal road traffic accidents in the UK', Accident Analysis and Prevention, 42(2), pp. 764-770.

Clarke, R.V. and Felson, M (1993) Routine Activity and Rational Choice. London: Transaction Publishers. 
Cohen, A.K. (2005) 'A General Theory of Subcultures', in Gelder, K. (ed.) The Subcultures Reader. 2nd edn. London: Routledge, pp. 1-18.

College of Policing (2013) Road policing. Available at:

https://www.app.college.police.uk/app-content/road-policing-2/ (Accessed: 29 June 2017).

Conner, M., Sherlock, K. and Orbell, S. (1998) 'Psychological determinants of ecstasy use in young people in the UK', British Journal of Health Psychology, 3(4), pp. 295-317.

Criminal Justice Act 1967. Available at:

http://www.legislation.gov.uk/ukpga/1967/80/contents (Accessed: 30 May 2017).

Criminal Justice Act 1988. Available at:

http://www.legislation.gov.uk/ukpga/1988/33/contents (Accessed: 30 May 2017).

Crown Prosecution Service (2014) Narrowing the Justice Gap. Available at:

http://www.cps.gov.uk/publications/prosecution/justicegap.html (Accessed: 16 October 2017).

Crown Prosecution Service (2016a) Out-of-Court Disposals. Available at: https://www.cps.gov.uk/publications/code for crown prosecutors/disposals.html (Accessed: 21 August 2016).

Crown prosecution Service (2016b) Youth Offenders. Available at: http://www.cps.gov.uk/legal/v_to_z/youth_offenders/index.html\#a12 (Accessed: 16 October 2017).

Deehan, A. and Saville, E. (2003) Calculating the risk: recreational drug use among clubbers in the South East of England. London: Home Office.

Department for Transport (2013) Driving under the influence of drugs: Report from the expert panel on drug driving. Available at:

https://www.gov.uk/government/uploads/system/uploads/attachment data/file/167971/drug -driving-expert-panel-report.pdf (Accessed: 29 June 2017).

Driver and Vehicle Licencing Authority (2015) How many people hold licences in the UK?. Available at:

https://www.gov.uk/government/uploads/system/uploads/attachment data/file/397430/FOI R4341 How many people hold licences in the UK.pdf (Accessed: 2 July 2016). 
Farrington, D.P., Coid, J.W., Harnett, L.M., Jolliffe, D., Soteriou, N., Turner, R.E. and West, D.J. (2006) Criminal careers up to age 50 and life success up to age 48: New findings from the Cambridge Study in Delinquent Development. London: Home Office (Research Study No. 299).

Felson, M. (1986) 'Linking Criminal Choices, Routine Activities, Informal Control, and Criminal Outcomes', in Cornish, D.B. and Clarke, R.V. (eds.) The Reasoning Criminal: Rational Choice Perspectives on Offending. New York, NY: Springer-Verlag, pp. 119-128.

Firearms Act 1968. Available at: http://www.legislation.gov.uk/ukpga/1968/27/contents (Accessed: 30 May 2017).

Fraud Act 2006. Available at: http://www.legislation.gov.uk/ukpga/2006/35/contents (Accessed: 30 May 2017).

Freeman, J., Liossis, P., Schonfeld, C., Sheehan, M., Siskind, V. and Watson, B. (2006) 'The self-reported impact of legal and non-legal sanctions on a group of recidivist drunk drivers', Transportation Research Part F, 9, pp. 53-64.

Garland, D. (2009) 'The new criminologies of everyday life', in Newburn, T. (ed.) Key Readings in Criminology. Abingdon: Willan Publishing, pp. 304-306.

Grasmick, H.G., Bursik, R.J. (1990) 'Conscience, Significant Others, and Rational Choice: Extending the Deterrence Model', Law and Society Review, 24(3), pp. 837-862.

Grasmick, H.G., Bursik, R.J. and Arneklev, B.J. (1993) 'Reduction in drunk driving as a response to increased threats of shame, embarrassment, and legal sanctions', Criminology, 31(1), pp. 41-67.

Groeger, J.A. (2011) 'How Many E's in Road Safety?', in Porter, B.E. (ed.) Handbook of Traffic Psychology. London: Elsevier. pp. 3-12.

Hagan, J., Simpson, J.H. and Gillis, A.R. (1979) 'The Sexual Stratification of Social Control: A Gender-Based Perspective on Crime and Delinquency', The British Journal of Sociology, 30(1), pp. 25-38.

Heidensohn, F. (1968) 'The Deviance of Women: A Critique and an Enquiry', The British Journal of Sociology, 19(2), pp. 160-175. 
Heidensohn, F. (2010) 'On writing 'The deviance of women': observations and analysis', The British Journal of Sociology, 61(Issue Supplement s1), pp. 127-132.

Home Office (2014a) Drug misuse: Findings from the 2013/14 Crime Survey for England and Wales. Available at: https://www.gov.uk/government/publications/drug-misusefindings-from-the-2013-to-2014-csew/drug-misuse-findings-from-the-201314-crime-surveyfor-england-and-wales (Accessed: 3 July 2016).

Home Office (2014b) Police National Computer (PNC). Available at:

https://www.gov.uk/government/uploads/system/uploads/attachment data/file/488515/PN C v5.0 EXT clean.pdf (Accessed: 16 June 2017).

Jacobs, B.A. (1999) Dealing Crack: The Social World of Streetcorner Selling. Boston MA: Northeastern University Press.

MacLeod, J.F., Grove, P.G. and Farrington, D.P. (2012) Explaining Criminal Careers: Implications for Justice Policy, Oxford: Oxford University Press.

Miller, J. (2013) 'Individual Offending, Routine Activity, and Activity Settings: Revisiting the Routine Activity Theory of General Deviance', Journal of Research in Crime and Delinquency, 50(3), pp. 390-416.

Ministry of Justice (2014) Statistics on Women and the Criminal Justice System 2013. Available at:

https://www.gov.uk/government/uploads/system/uploads/attachment data/file/380090/wo men-cjs-2013.pdf (Accessed: 3 July 2016).

Ministry of Justice (2016) Criminal Justice Statistics 2015: England and Wales. Available at:

https://www.gov.uk/government/uploads/system/uploads/attachment data/file/524429/crim inal-justice-statistics-quarterly-update- annual -2015.pdf (Accessed: 6 July 2016).

Misuse of Drugs Act 1971. Available at:

http://www.legislation.gov.uk/ukpga/1971/38/contents (Accessed: 4 May 2015).

Moskowitz, H. (1976) 'Marihuana and Driving', Accident Analysis and Prevention, 8, pp. 21-26. 
Newburn, T. (2009) 'Chapter 14: Contemporary classicism: Introduction', in Newburn, T. (ed.) Key Readings in Criminology. Abingdon: Willan Publishing, pp. 302-303.

OECD (1997) Road Safety Principles and Models: Review of Descriptive, Predictive, Risk and Accident Consequence Models. Paris: Organisation for Economic Co-operation and Development.

Offences Against the Persons Act 1861. Available at: http://www.legislation.gov.uk/ukpga/Vict/24-25/100/contents (Accessed: 30 May 2017).

O'Grady, W., Asbridge, M. and Abernathy, T. (2000) 'Illegal tobacco sales to youths: A view from rational choice theory, Canadian Journal of Criminology, 42(1), pp. 1-20.

O'Malley, O. and Valverde, M. (2004) 'Pleasure, Freedom and Drugs: The Uses of 'Pleasure' in Liberal Governance of Drug and Alcohol Consumption', Sociology, 38(1), pp. 25-42.

Orbell, S., Blair, C., Sherlock, K. and Conner, M. (2001) 'The Theory of Planned Behavior and Ecstasy Use: Roles for Habit and Perceived Control Over Taking Versus Obtaining Substances', Journal of Applied Social Psychology, 31(1), pp. 31-47.

Osgood, W.D., Wilson, J.K., O'Malley, P.M., Bachman, J.G. and Johnston, L.D. (1996) 'Routine Activities and Individual Deviant Behavior', American Sociological Review, 61(4), pp. 635-655.

Paternoster, R. (1989) 'Decisions to Participate in and Desist from Four Types of Common Delinquency: Deterrence and the Rational Choice Perspective', Law and Society Review, 23(1), pp. 7-40.

Police Act 1996. Available at: http://www.legislation.gov.uk/ukpga/1996/16/contents (Accessed: 30 May 2017).

Police Reform Act 2002. Available at: http://www.legislation.gov.uk/ukpga/2002/30/contents (Accessed: 30 May 2017).

Prevention of Crime Act 1953. Available at: http://www.legislation.gov.uk/ukpga/Eliz2/12/14/contents (Accessed: 30 May 2017). 
Protection from Harassment Act 1997. Available at:

http://www.legislation.gov.uk/ukpga/1997/40/contents (Accessed: 30 May 2017).

Public Meeting Act 1908. Available at:

http://www.legislation.gov.uk/ukpga/Edw7/8/66/contents (Accessed: 30 May 2017).

Public Order Act 1986. Available at: http://www.legislation.gov.uk/ukpga/1986/64/contents (Accessed: 30 May 2017).

Rado, S. (1957) 'Narcotic Bondage: A General Theory of the Dependence on Narcotic Drugs', The American Journal of Psychiatry, 114(2), pp. 165-170.

Reed, M., Evely, A.C., Cundill, G., Fazey, I.R.A., Glass, J., Laing, A., Newig , J., Parrish, B., Prell, C., Raymond, C. and Stringer, L. (2010) 'What is social learning?', Ecology and Society, 15(4). Available at: http://www.ecologyandsociety.org/vol15/iss4/ (Accessed: 20 August 2016.

Roach, J. (2017) 'Self-selection Policing and the Disqualified Driver', Policing.Available at: https://academic.oup.com/policing/article/2951290 (Accessed: 19 September 2017).

Roach, J., and Pease, K. (2016) Self-Selection Policing: An Introduction to Theory, Research and Practice. Basingstoke, Hampshire: Palgrave Macmillan.

Road Traffic Act 1988. Available at: http://www.legislation.gov.uk/ukpga/1988/52/contents (Accessed: 30 May 2017).

Road Traffic Act 1988, section 4. Available at: http://www.legislation.gov.uk/ukpga/1988/52/section/4 (Accessed: 5 May 2015).

Road Traffic Act 1988, section 5A. Available at:

http://www.legislation.gov.uk/ukpga/2013/22/part/3/crossheading/drugs-anddriving/enacted?view=plain (Accessed: 4 May 2015).

Rock, P. (2012) 'Sociological Theories of Crime', in Maguire, M., Morgan, R and Reiner, R. (eds.) The Oxford Handbook of Criminology. 5th edn. Oxford: Oxford University Press, pp. 38-80.

Rose, G. (2000) Criminal Histories of Serious Traffic Offenders. London: Home Office, Policing and Reducing Crime Unit. 
Sampson, R.J. and Laub, J.H. (1990) 'Crime and Deviance over the Life Course: The Salience of Adult Social Bonds', American Sociological Review, 55(5), pp. 609-627.

Silvestri, M. and Crowther-Dowey, C. (2016) Gender and Crime: A Human Rights Approach. 2nd edn. London: Sage Publications Ltd.

Stafford, M.C. and Warr, M. (1993) 'A reconceptualization of general and specific deterrence', Journal of Research in Crime and Delinquency, 30(2), pp. 123-135.

Steffensmeier, D. and Allan, E. (1996) 'Gender and Crime: Toward a Gendered Theory of Female Offending', Annual Review of Sociology, 22, pp. 459-487.

Waddington, P.A.J., Stenson, K. and Don, D. (2009) 'In proportion: race, and police stop and search', in Newburn, T. (ed.) Key Readings in Criminology. Abingdon: Willan Publishing, pp. 754-759.

Warr, M. (1998) 'Life-Course Transitions and Desistance from Crime', Criminology, 36(2), pp. 182-216.

Watson, B., Siskind, V., Fleiter, J.J., Watson, A. and Soole, D. (2015a) 'Assessing specific deterrence effects of increased speeding penalties using four measures of recidivism', Accident Analysis and Prevention, 84, pp. 27-37.

Watson, B., Watson, A., Siskind, J., Fleiter, J. and Soole, D. (2015b) 'Profiling high-range speeding offenders: Investigating criminal history, personal characteristics, traffic offences, and crash history', Accident Analysis and Prevention, 74, pp. 87-96.

Zaal, D. (1994) Traffic Law Enforcement: A Review of the Literature. (Report No. 53). Melbourne: Monash University Accident Research Centre. 